ФИЗИКА КОНДЕНСИРОВАННОГО СОСТОЯНИЯ

DOI: $10.5862 / J P M .248 .1$

UDC 538.975: $620.22-022.53$

\author{
R.G. Burkovsky ', D.A. Andronikova ', \\ Yu. A. Bronwald ', A.V. Filimonov', S.B. Vakhrushev ${ }^{2,3}$ \\ 1 Peter the Great St. Petersburg Polytechnic University \\ ${ }^{2}$ Ioffe Physical Technical Institute of the Russian Academy of Sciences, \\ St. Petersburg, Russian Federation \\ ${ }^{3}$ St. Petersburg University
}

\title{
AN ANALYSIS OF THE PHONON DISPERSION CURVES OF LEAD HAFNATE IN THE CUBIC PHASE USING LATTICE-DYNAMICAL MODELS
}

\begin{abstract}
We have analyzed the phonon dispersion curves in the paraelectric phase of a lead hafnate crystal $\left(\mathrm{PbHfO}_{3}\right)$ by means of two different lattice-dynamical models. Both the rigid-ion model and the shell one provided an acceptable description of the available experimental data. The atomic displacement patterns were qualitatively different for the two models. In the rigid-ion model the motion in the characteristic low-energy flattened transverse acoustic branch contained both lead and hafnium displacements, while for the shell model it corresponded mainly to lead displacements with the small contribution of oxygen displacements. The shell model allows simultaneous description of the phonon dispersion curves and the correct value of the dielectric constant.
\end{abstract}

ANTIFERROELECTRIC, LEAD HAFNATE, LATTICE DYNAMICS, SHELL MODEL.

\section{Introduction}

Lead-based perovskites find numerous applications in technology. They are used in high-performance piezoelectric ceramics [1], electrooptical materials [2] and non-volatile random access memory [3]. Antiferroelectric materials attract particular interest because their lattice dynamics has not been completely understood up to the present. The classical antiferroelectrics $\mathrm{PbZrO}_{3}$ and $\mathrm{PbHfO}_{3}$ exhibit a critical increase in the dielectric permittivity upon approaching the phase transition [4]. This indicates the presence of a soft ferroelectric phonon mode. On the other hand, the phase transition leads to the formation of the antiferroelectric phase [5] instead of the ferroelectric one. The physical reason for the formation of the antipolar order in these materials is currently not completely clear. Under small doping by ferroelectric additions, classical antiferroelectric $\mathrm{PbZrO}_{3}$ undergoes phase transitions to incommensurate phases [6], which have an even more complex form of structural modulation than antiferroelectricity. Until recently, there was no information on the phonon dispersion of lead-based antiferroelectrics. It has been shown that $\mathrm{PbZrO}_{3}$ single crystals have transverse acoustic (TA) phonon branch, which is highly flattened at finite wavevectors in the $\left[\begin{array}{lll}1 & 1 & 0\end{array}\right]$ pseudocubic direction [7]. In the following study on $\mathrm{PbHfO}_{3}$ we have shown an anti-crossing between the transverse acoustic and low energy optic branches [8]. In that paper we used the simplest rigid-ion model for describing the dispersion curves.

Here we consider a more elaborate and commonly used shell model [9] which accounts for the electronic polarizability of ions. The results of the description within these two models are compared to each other in terms 
of the predicted phonon energies and the polarization eigenvectors.

\section{Analysis method}

The rigid-ion model was initially introduced by Kellermann for describing the dispersion curves in sodium chloride [10]. Later on it was adapted by Cowley for modeling the lattice dynamics in perovskites [9]. This model is the simplest one to account for the effects of electric fields created when charged ions are displaced from their equilibrium positions. In the case of perovskite structure the rigid-ion model has eight independent parameters: six constants describing the central short-range forces between the nearest neighbor ions and two constants defining the charges of the ions. The charge of the third ion is determined by the condition of electroneutrality of the unit cell. To fit the model we took the experimental data (wavevectors, energies and energy determination uncertainities), corresponding to
$T=773 \mathrm{~K}$ from Ref. [8]. We used all the available experimental points for transverse and longitudinal phonons in [ $\left[\begin{array}{lll}1 & 0 & 0\end{array}\right]$ and $\left[\begin{array}{lll}1 & 1 & 0\end{array}\right]$ directions simultaneously. The lattice constant was taken as $a=4.15 \AA$. The least-squares fits were accomplished using Matlab software.

The shell model (SM) was first introduced by Woods, Cochran and Brockhouse [11] for describing phonons in alkali halides and adapted for use with perovskite structure by Cowley [9]. In the present work, we used the SM slightly modified to account for anisotropy of oxygen polarizability, as it was done by Fontana et al. [12] for $\mathrm{KNbO}_{3}$. In addition to the experimental data determined by inelastic X-ray scattering, we used with the SM an additional experimental point, which is the value of the dielectric constant of the material (we took $\varepsilon$ as about $575 \pm 50$ [4]). The model dielectric constant was calculated by the method discussed by Cowley [9]. In order to improve the conditionality of the fitting problem we have fixed the
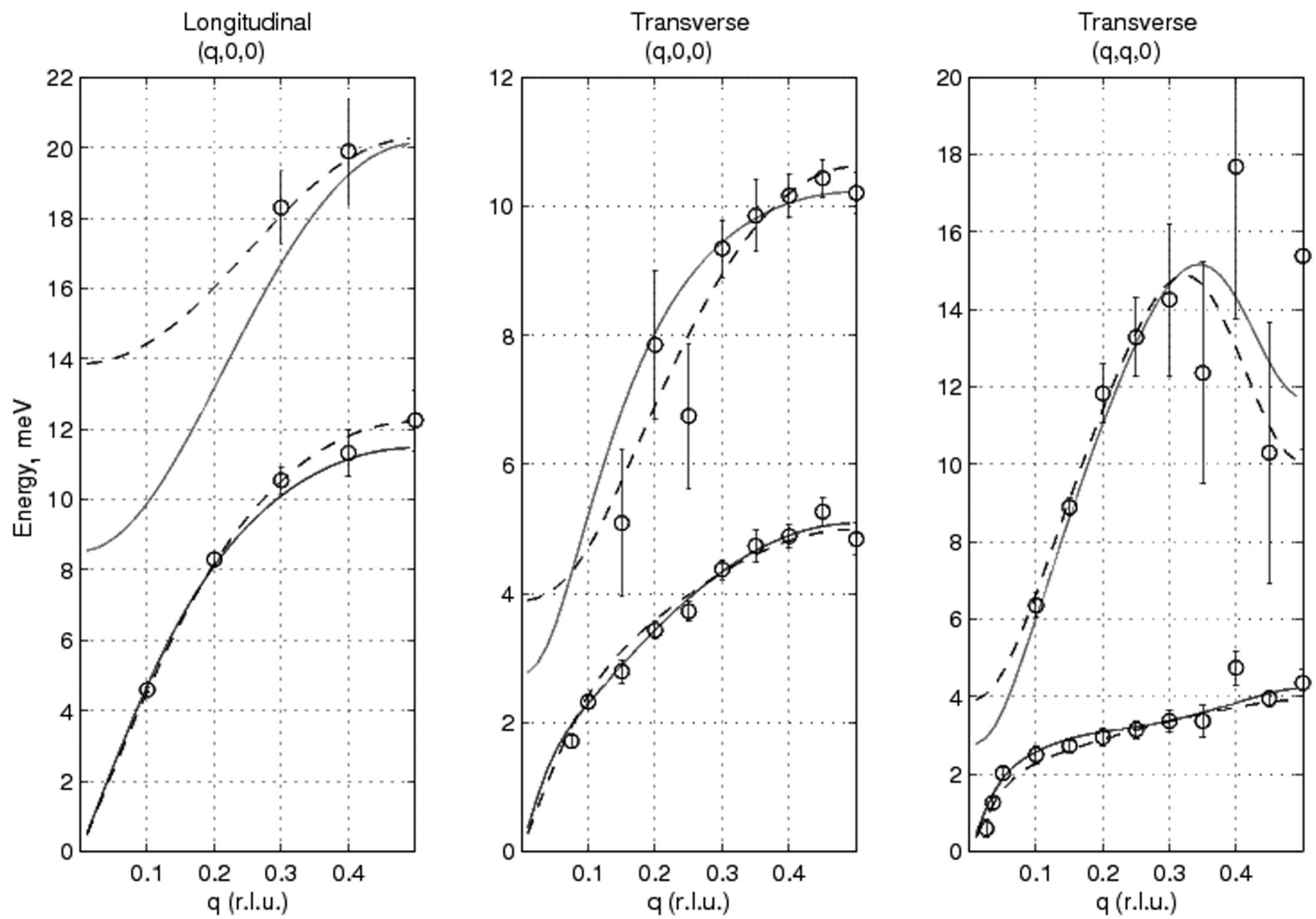

Fig. 1. Experimentally determined dispersion curves (symbols), the rigid-ion model fit (dashed lines) and the SM fit (solid lines). Each panel shows one acoustic (lower energy) and one optical (higher energy) phonon branch 
electronic polarizabilities of $\mathrm{Pb}$ and $\mathrm{Hf}$ to their expected values. For $\mathrm{Pb}$ we used $\alpha=4.9 \AA^{3}$ [13] and for $\mathrm{Hf}$ we used the value known for the chemically similar $\operatorname{Zr}\left(\alpha=0.47 \AA^{3}\right.$ [13]).

\section{Results and discussion}

Fig. 1 shows the experimentally determined phonon energies together with the results of the fits by the two models. The result of the fit by the rigid-ion model is shown by dashed lines, while the SM fit is shown by solid lines. Both models provide an adequate description of the characteristic flattened transverse acoustic branch in the $(q, q, 0)$ direction and the avoided crossing between the acoustic and optic branches. Both models reproduce the change in the group velocity for the optic branch in $(q, q, 0)$ direction at $q=0.35$. The models give notably different frequencies for the small-wavevector optical branches, where there were no experimental data to directly fit to.
The largest difference is observed for the longitudinal optical branch. The zonecenter frequency of the transverse optical (ferroelectric) mode is notably lower for the SM.

The two models give different patterns of the ionic displacements in the phonon branches. In the case of the rigid-ion model the fit indicates that the TA branch in the $(q, q, 0)$ direction, for $q>0.1$, corresponds mainly to the motion of lead and hafnium with the lead displacements about 2 times larger than the hafnium ones. In the case of the shell model the displacements in this branch are mostly due to $\mathrm{Pb}$ with a small addition of the oxygen displacement (about 15 percent of that of $\mathrm{Pb}$ ). The result of the shell model appears to be more logical. The hafnium ion has a large ionic radius and, thus, is not expected to participate intensively in the phonon modes with small energy. On the other hand, the lead

Table 1

The comparison between the parameters of the two lattice-dynamical models describing the phonon dispersion curves

\begin{tabular}{|c|c|c|c|}
\hline \multirow{2}{*}{ Description } & \multirow{2}{*}{ Parameter } & \multicolumn{2}{|c|}{ Value } \\
\cline { 2 - 4 } & $A_{1}$ & RIM & SM \\
\cline { 2 - 4 } & $B_{1}$ & -3.944 & 0.15 \\
\cline { 2 - 4 } $\begin{array}{c}\text { Short-range force } \\
\text { constant, } e^{2} / 2 v_{a}\end{array}$ & $A_{2}$ & 289.1 & 208.1 \\
\cline { 2 - 4 } & $B_{2}$ & -63.09 & -24.07 \\
\cline { 2 - 4 } & $A_{3}$ & -11.220 & 5.237 \\
\cline { 2 - 4 } & $B_{3}$ & 3.595 & 0.860 \\
\hline \multirow{2}{*}{ Ion charge, $E$} & $Z_{1}$ & 1.700 & 2.275 \\
\cline { 2 - 4 } & $Z_{2}$ & 4.070 & 3.000 \\
\hline
\end{tabular}

Abbreviations: RIM and SM are the rigid-ion and the shell model, respectively

Table 2

The remaining parameters of the shell model describing the phonon dispersion curves

\begin{tabular}{|c|c|c|c|c|c|}
\hline \multicolumn{2}{|c|}{ Electronic polarizability } & Short-range polarizability & Core-shell force constants \\
\hline \multicolumn{2}{|c|}{$v_{a}$} & \multicolumn{2}{c|}{$e$} & \multicolumn{2}{c|}{$e^{2} / v_{a}$} \\
\hline$\alpha_{1}$ & $\alpha_{2}$ & $d_{1}$ & $d_{2}$ & $k_{31}$ & $k_{32}$ \\
\hline 0.06856 & 0.006576 & -0.741 & -0.250 & 117 & 70 \\
\hline
\end{tabular}


ion is expected to move intensively in the lowenergy modes because of its small ionic radius as compared to the available space in the large unit cell of $\mathrm{PbHfO}_{3}$.

The parameters of the fits using the rigidion model and the shell model are listed in Tables 1 and 2. Similar to the data on $\mathrm{SrTiO}_{3}$, the short-range force constants are generally larger in magnitude for the shell model. In the case of the shell model the dielectric constant corresponding to the fit is 527, which is reasonably close to the experimental value of about 575 at high temperatures. Like other perovskites, the $\mathrm{SM}$ fit for $\mathrm{PbHfO}_{3}$ gives a strongly negative oxygen shell charge: about -2.7 electrons. By analogy with the analysis performed by Cowley for $\mathrm{SrTiO}_{3}$ [9], we have analyzed the anisotropy of the oxygen polarizability. In the directions parallel to the corresponding $\mathrm{Pb}-\mathrm{O}$ planes the polarizability is $4.4 \AA^{3}$, while in the direction towards hafnium it is only $1.8 \AA^{3}$. This anisotropy of oxygen polarizability may be important for further understanding of the microscopic reason for the flattened TA branch.

\section{Conclusion}

We have performed the analysis of the phonon dispersion curves of $\mathrm{PbHfO}_{3}$ crystals in the paraelectric phase using two latticedynamical models. Both models provide an adequate description of the available data. The shell model, in addition to the actual dispersion curves, provides a reasonable value for the dielectric constant confirming the reliability of the ionic displacement patterns provided by this model.

\section{Acknowledgements}

R. Burkovsky acknowledges the support by Grant of the President of the Russian Federation for state support of Russian young scientists MK-5685.2016.2.

D. Andronikova and Yu. Bronwald acknowledge the support of RFBR (grant 16-02-01162). The work of Yu. Bronwald and A. Filimonov was performed under the government order of the Ministry of Education and Science of RF.

Грант президента Российской Федерации MK-5685.2016.2

\section{REFERENCES}

[1] J.F. Scott, Applications of modern ferroelectrics, Science 315 (5814) (2007) 954-959.

[2] G.H. Haertling, Ferroelectric ceramics: history and technology, J. Am. Ceram. Soc. 82 (4) (1999) 797-818.

[3] X. Wei, A. Tagantsev, A. Kvasov, et al. Ferroelectric translational antiphase boundaries in nonpolar materials, Nature communications 5 (2014) Article number 3031.

[4] G. Samara, Pressure and temperature dependence of the dielectric properties and phase transitions of the antiferroelectric perovskites: $\mathrm{PbZrO}_{3}$ and $\mathrm{PbHfO}^{3}$, Phys. Rev., B. 1(9) (1970) 3777-3785.

[5] D. Corker, A. Glazer, W. Kaminsky, et al., Investigation into the crystal structure of the perovskite lead hafnate, $\mathrm{PbHfO}_{3}$, Acta Crystallographica, Section B: Structural Science. B54 (Part 1) (1998) 18-28.

[6] I. MacLaren, R. Villaurrutia, B. Schaffer, et al., Atomic-scale imaging and quantification of electrical polarisation in incommensurate antiferroelectric lanthanum-doped lead zirconate titanate, Advanced Functional Materials. 22(2) (2012) 261-266.
[7] A.K. Tagantsev, K. Vaideeswaran K., S.B. Vakhrushev, et al., The origin of antiferroelectricity in $\mathrm{PbZrO}_{3}$, Nature Communications, 4, art. No. 3229, (2013).

[8] R. Burkovsky, D. Andronikova, Yu. Bronwald, et al., Lattice dynamics in the paraelectric phase of $\mathrm{PbHfO}^{3}$ studied by inelastic X-ray scattering, Journal of Physics Condensed Matter, 27 (33) (2015) 335901-336000.

[9] R.A. Cowley, Lattice dynamics and phase transitions of strontium titanate, Phys. Rev. 134 (4A) (1964) A981-A997.

[10] E.W. Kellermann, Theory of the vibrations of the sodium chloride lattice, Phil. Trans. R. Soc. Lond., A. 238 (1940) 513-548.

[11] A.D.B. Woods, W. Cochran, B.N. Brockhouse, Lattice dynamics of alkali halide crystals, Phys. Rev. 119 (3) (1960) 980-999.

[12] M. Fontana, Lattice dynamics of the cubictetragonal phase transition in $\mathrm{KNbO}_{3}$, Journal de Physique. 42 (C6) (1981) 749-751.

[13] J.R. Tessman, A. Kahn, W. Shockley, Electronic polarizabilities of ions in crystals, Phys. Rev. 92 (4) (1953) 890-895. 


\title{
THE AUTHORS
}

BURKOVSKY Roman G.

Peter the Great St. Petersburg Polytechnic University

29 Politechnicheskaya St., St. Petersburg, 195251, Russian Federation

roman.burkovsky@gmail.com

\author{
ANDRONIKOVA Dariya A. \\ Peter the Great St. Petersburg Polytechnic University \\ 29 Politechnicheskaya St., St. Petersburg, 195251, Russian Federation \\ andronikova.daria@gmail.com
}

\section{BRONWALD Yuriy A.}

Peter the Great St. Petersburg Polytechnic University

29 Politechnicheskaya St., St. Petersburg, 195251, Russian Federation

yuramel@gmail.com

\section{FILIMONOV Aleksey V.}

Peter the Great St. Petersburg Polytechnic University

29 Politechnicheskaya St., St. Petersburg, 195251, Russian Federation

filimonov@rphf.spbstu.ru

\section{VAKHRUSHEV Sergey B.}

Ioffe Physical Technical Institute of the Russian Academy of Sciences Peter the Great

St. Petersburg Polytechnic University

26 Polytekhnicheskaya St., St. Petersburg, 194021, Russian Federation

s.vakhrushev@mail.ioffe.ru

\section{Бурковский Р.Г., Андроникова Д.А., Бронъальд Ю.А., Филимонов А.В., ВахрушеВ С.Б. АНАЛИЗ ФОНОННЫХ ДИСПЕРСИОННЫХ КРИВЫХ ГАФНАТА СВИНЦА В КУБИЧЕСКОЙ ФАЗЕ НА ОСНОВЕ МОДЕЛЕЙ ДИНАМИКИ РЕШЕТКИ.}

Приведен анализ фононных дисперсионных кривых в параэлектрической фазе кристаллов гафната свинца $\left(\mathrm{PbHfO}_{3}\right)$ с использованием двух различных моделей динамики решетки. Модель жестких ионов и оболочечная модель обеспечивают удовлетворительное описание доступных экспериментальных данных. Паттерны атомных смещений являются качественно различными для двух моделей. В случае модели жестких ионов движение, соответствующее характерной низкоэнергетической плоской поперечной акустической ветви, содержит смещения свинца и гафния. В то же время, для оболочечной модели такое движение соответствует в основном динамическим смещениям свинца с малым вкладом смещений кислорода.

АНТИСЕГНЕТОЭЛЕКТРИК, ГАФНАТ СВИНЦА, ДИНАМИКА РЕШЕТКИ, ОБОЛОЧЕЧНАЯ МОДЕЛЬ.

\section{СПИСОК ЛИТЕРАТУРЫ}

[1] Scott J.F., Applications of modern ferroelectrics // Science. 2007. Vol. 315. Iss. 5814. Pp. 954-959.

[2] Haertling G.H. Ferroelectric ceramics: history and technology // J. Am. Ceram. Soc. 1999. Vol. 82. No. 4. Pp. 797-818.

[3] Wei X., Tagantsev A., Kvasov A., et al. Ferroelectric translational antiphase boundaries in nonpolar materials //Nature communications. 2014. Vol. 5. Art. No. 3031.

[4] G. Samara, Pressure and temperature dependence of the dielectric properties and phase transitions of the antiferroelectric perovskites: $\mathrm{PbZrO}_{3}$ and $\mathrm{PbHfO}^{3} / /$ Phys. Rev. B1. 1970. Vol. 1. No. 9. 3777-3785.

[5] Corker D., Glazer A., Kaminsky W., et al. Investigation into the crystal structure of the perovskite lead hafnate, $\mathrm{PbHfO}_{3} / /$ Acta Crystallographica. Sec. B: Structural Science. 1998. Vol. B54. Part 1. Pp. 18-28.

[6] MacLaren I., Villaurrutia R., Schaffer B., et al. Atomic-scale imaging and quantification 
of electrical polarisation in incommensurate antiferroelectric lanthanum-doped lead zirconate titanate //Advanced Functional Materials. 2012. Vol. 22 . No. 2. Pp. 261-266.

[7] Tagantsev A.K., Vaideeswaran K., Vakhrushev S.B., et al., The origin of antiferroelectricity in $\mathrm{PbZrO}_{3} / /$ Nature Communications. 2013. Vol. 4. Art. No. 3229.

[8] Burkovsky R., Andronikova D., Bronwald Yu., et al. Lattice dynamics in the paraelectric phase of $\mathrm{PbHfO}_{3}$ studied by inelastic X-ray scattering // J. Phys. Cond. Matt. 2015. Vol. 27. No. 33. Pp. $335901-336000$.

[9] Cowley R.A. Lattice dynamics and phase transitions of strontium titanate // Phys. Rev. A. 1964. Vol. 134. No. 4A. Pp. A981- A997.

[10] Kellermann E.W. Theory of the vibrations of the sodium chloride lattice // Phil. Trans. R. Soc. Lond. A. 1940. Vol. 238. Pp. 513-548.

[11] Woods A.D.B., Cochran W., Brockhouse B.N. Lattice dynamics of alkali halide crystals // Phys. Rev. 1960. Vol. 119. No. 3. Pp. 980-999.

[12] Fontana M. Lattice dynamics of the cubictetragonal phase transition in $\mathrm{KNbO} 3 / /$ Journal de Physique. 1981. Vol. 42. No. C6. Pp. 749-751.

[13] Tessman J.R., Kahn A., Shockley W. Electronic polarizabilities of ions in crystals // Phys. Rev. 1953. Vol. 92. No. 4. Pp. 890-895.

\section{СВЕДЕНИЯ ОБ АВТОРАХ}

БУРКОВСКИЙ Роман Георгиевич - кандидат физико-математических наук, доцент кафедры физической электроники Санкт-Петербургского политехнического университета Петра Великого.

195251, Российская Федерация, г. Санкт-Петербург, Политехническая ул., 29

roman.burkovsky@gmail.com

АНДРОНИКОВА Дарья Александровна - инженер кафедры физической электроники СанктПетербургского политехнического университета Петра Великого.

195251, Российская Федерация, г. Санкт-Петербург, Политехническая ул., 29

andronikova.daria@gmail.com

БРОНВАЛЬД Юрий Алексеевич - аспирант кафедры физической электроники СанктПетербургского политехнического университета Петра Великого.

195251, Российская Федерация, г. Санкт-Петербург, Политехническая ул., 29

yuramel@gmail.com

ФИЛИМОНОВ Алексей Владимирович - доктор физико-математических наук, заведуюший кафедрой физической электроники Санкт-Петербургского политехнического университета Петра Великого.

195251, Российская Федерация, г. Санкт-Петербург, Политехническая ул., 29

filimonov@rphf.spbstu.ru

ВАХРУШЕВ Сергей Борисович - доктор физико-математических наук, профессор кафедры нейтронной и синхротронной физики Санкт-Петербургского государственного университета, заведующий лабораторией Физико-технического института им. А.Ф. Иоффе РАН.

195251, Российская Федерация, г. Санкт-Петербург, Политехническая ул., 29

s.vakhrushev@mail.ioffe.ru 